\title{
Speech Act Analysis Of Madurese Wedding Ceremony In Kalidandan Village, Pakuniran, Probolinggo
}

\author{
Anwari \\ University of Muhammadiyah Kudus \\ anwari@umkudus.ac.id
}

DOI: https://doi.org/10.18326/jopr.v2i2.113-126

Copyright (C) The Author (s)

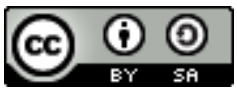

This work is licensed under a Creative Commons Attribution-ShareAlike 4.0 International License. How to Cite: Anwari, A. (2020). Speech Act Analysis of Madurese Wedding Ceremony in Kalidandan Village, Pakuniran, Probolinggo. Journal of Pragmatics Research, 2(2), 113-126. doi:https://doi.org/10.18326/jopr.v2i2.113-126

\begin{abstract}
SUBMISSION
TRACK:

Received:

25-07-2020

Final Revision:

02-10-2020

Available online:

15-10-2020

Corresponding

Author:

Anwari

anwari@umkudus.ac.id

ABSTRACT

Pragmatics is the study of those relations between language and context that are grammaticalized, or encoded in the structure of language. This study aims to describe kinds of speech act especially locutionary act, illocutionary act, and perlocutionary act of Madurese wedding ceremony in Kalidandan village, Pakuniran district, Probolinggo regency. The results of this study showed that illocutionary act of Madurese wedding ceremony in Kalidandan village, Pakuniran district, Probolinggo regency has various kinds of speech act, 1) direct speech act; 2) indirect speech act; 3) literal speech act; 4) non-literal speech act; 5) direct literal speech act; 6) indirect literal speech act; 7) direct non-literal speech act; and 8) indirect non-literal speech act.
\end{abstract}

Keywords: Speech act, Kinds of speech act, and Madurese

\section{INTRODUCTION}

Language is a system of sound used by humans to communicate and social interaction each other (Jendra, 2009). (Bawa, 2004) stated that language is an expression system that expresses thoughts, feelings, and psychomotor speakers of a language. Thoughts, feelings, and 
human psychomotor produce the product of culture and it includes the convention and tradition of the use relatively linguistic elements, it makes a group to talk, behave in social contexts and situations between one group and another (Foley, 1977).

Language used in contexts where speakers use language so they can communicate to understand text, context, and patterns or structure of the text (Yule, 1996). In this case, there is an assumption that every language has a meaning based on context of situations. No speech or utterance occurs without context of situations. Therefore, pragmatics is intended to be studied of how these intensions are realized through linguistic form

The meaning of language is very closely related to mode. However, each language has its own identity and uniqueness like pronunciation and accent. One of the uniqueness is manifested in the speech of Madurese wedding ceremony at Kalidandan village, Pakuniran, Probolinggo. The speech occurs in several sequences, namely engagement speech, pre-wedding speech, wedding speech, and post-wedding speech. Each speech contains different purposes depending on the context of situation. The variety of mode, functions, and meanings is determined based on the use of language through context of the speaker's situation.

Madurese in Kalidandan, Pakuniran, Probolinggo are Madurese who live in Java. Generally, Madurese is a language used by the speakers as means of daily communication both residing in Madura, surroundings of small islands and overseas. Madurese occupies around fifteen million speakers in Indonesia (Fetrina Rahma Dewi, 2010). Based on linguistics point of view, Madurese are grouped into five main dialects, namely 1) Bangkalan dialect; 2) Sampang dialect; 3) Pamekasan dialect; 4) Sumenep dialect; and 5) Kangean dialect.

Apart from Madura itself, Madurese is also used in Probolinggo. One of the uses is used in Kalidandan village, Pakuniran district, Probolinggo regency. The use of Madurese has the variety mode of communications. The Madurese of Kalidandan are totally 1.125 speakers. They communicate with Madurese in their daily life as it a mother tongue to interact with others. In addition, Madurese often found in social activities, such as in educational institution, arts, customs, and ritual. The use of Madurese is a means that can be understood by speakers and hearers. They have a direct relationship who provide a description of values, traditions, and culture.

Many speeches produced text and context in social communication (Hodge, 1988). There are two speeches that generally found in every culture and tradition, namely wedding speech and burial speech. One of the speeches used by Madures in Kalidandan village is 
Website: http://e-journal.iainsalatiga.ac.id/index.php/jopr/index

wedding speech. In general, the speech act of Madurese wedding ceremony in the city and village especially in Kalidandan are the same. It has sequence speech in communication, namely engagement speech, pre-wedding speech, wedding speech, and post-wedding speech.

A study done by Licea-Haquet et al., (2019) stated that language comprehension involves the recognition of speech acts. The term speech act refers to what a speaker intends to accomplish when saying something. Holtgraves (2008) demonstrated that English speakers can automatically recognize speech acts, and proposes that this allows an efficient (good-enough) processing of conversation turns. Other studies have found that speech act recognition requires cognitive process like executive functions, theory of mind, and empathy. However, there are few studies that have empirically investigated which are the cognitive functions needed for speech act recognition in healthy adults. The aim of this work was to study if Spanish speakers automatically recognize speech acts, and if this recognition is related to intellectual ability and other cognitive functions. He examined the question using the methods described by Holtgraves (2005, 2008). First, he translated and adapted the scenarios, and selected those that were better understood. Then, we designed two experiments to test the automatic recognition of speech acts. Participants underwent a battery of psychometric and cognitive tests. He found significant differences in reaction times between control and experimental scenarios, which indicates that Spanish speakers automatically recognize speech acts. A measure of intellectual ability, as well as the ability to reason about mental states of others, predicted in part the ability to recognize speech acts. In addition, Lipson et al., (2019) stated that illocutionary act of Na Gok Batak Toba wedding ceremony found 42 illocutionary acts namely 16 representative speech acts, 17 direct speech acts, 7 expressive speech acts, and 2 declarative speech acts. Meanwhile, a study done by Laily Nur Zahrina, (2016) showed that the marriage ceremony of the Watmuri community found directive speech acts, the act of recited speech in the family gathering procession commonly called kabotkit. The second, directive speech act in the marriage ceremony procession enter the usual called the bebetu. The third, the procession of marriage ceremony took the girl from her house is called kalabasa. The last is paying that the treasure commonly called by kesit. The four processions in traditional ceremonies of marriage have of use of directive speech acts, namely command and petition. The speech act is important to study especially Madurese in Kalidandan, Pakuniran, Probolinggo because they have some variety of communication in their daily life. One of them is speech act of wedding ceremony. The speech 
act of Madurese wedding ceremony in Kalidandan, Pakuniran, Probolinggo has utterance role. It has relationship between text and context. It means that the speech wedding ceremony has a unity structure which refers to form and content of the message. It has a discourse that refers to the text structure, namely opening, body, and closing. Simultaneously, these structures constructed meaning to describe language functions and its goals. Therefore, this research aims to describe kinds of speech act especially locutionary act, illocutionary act, and perlocutionary act of Madurese wedding ceremony in Kalidandan village, Pakuniran district, Probolinggo regency.

\section{RESEARCH METHOD}

This research is qualitative research which is to describe the nature, circumstances, and linguistic form of the use Madurese. Qualitative research is the research to carry out of natural setting or context of an entity (Moleong, 2004). The data of this study is primary data, namely oral data in the field through Madurese speech wedding ceremony in Kalidandan village, Pakuniran, Probolinggo.

Data were collected by listening technique, it means that the researcher directly listened to the use of Madurese that used by the speakers. (Tarigan, 1983) stated that listening is an activity to obtain information and understand meaning of communication that delivered by speakers through speech. Listening is basically considered as equivalent to observe in social research (Sudaryanto, 1993). This technique is supported by recording and transcribing data. Therefore, the language used by Madurese recorded and grouped into kind of speech.

\section{RESULTS \&DISCUSSION}

Speech Acts are communicative activities achieved in relation to the speaker's intention and the hearer's interpretation in a certain situation under certain social conventions. Theories of Speech Acts usually deal with pragmatic meanings generated by speakers' utterances as well as the effects of these utterances on the hearer's part. In other words, most Speech Act frameworks examine those types of things speakers do in uttering sentences and to a great degree the way the hearer reacts or executes the speaker's intention. Speech act theory attempts to explain how speakers use language to accomplish intended actions and how hearers infer intended meaning from what is said (Tsoumou, 2020). 
Website: http://e-journal.iainsalatiga.ac.id/index.php/jopr/index

Many authors have proposed several classifications for Speech Acts, all of which take off from Austin's (1962) seminars and lectures. Austin is usually regarded as a pioneer in developing a fresh-start theory of speech acts and laying down the three influential components of an utterance: locutionary, illocutionary and perlocutionary acts, on which most authors have subsequently based their models (Searle, 1969, 1975; Yoschitake, 2004; Weigand, 2010). A locutionary act is an actual utterance; an illocutionary act is the force behind the utterance; and a perlocutionary act is the effect of an utterance on the listeners.

John Searle extended Austin's concept of speech acts and elaborated on the Speech Act Theory by identifying the conditions that are necessary for the realization of speech acts. For example, to promise, the speaker needs sincerity and intentionality; to declare the marital union of two partners, a priest or a judge must be present. Hence, the successful performance of a speech act depends on whether the constituent conditions are fulfilled and realized in a contextually appropriate manner. Searle also proposed an illocutionary acts classification that includes: assertive acts, by which the speaker says how something is; directive acts, by which the speaker tries to get the hearer to perform some future action, such as requesting and warning; commissive acts, by which the speaker commits to some future course of action, such as pledging and promising; expressive acts, which allow the speaker to articulate his or her psychological state of mind about some prior action, such as apologizing and thanking; and declarative acts, which require non-linguist institutions, such as christening or sentencing (Licea-Haquet et al., 2019).

In general, speech acts are divided into three types of speech, namely locutionary act, illocutionary act, and perlocutionary act (Austin, 1962); (Searle, 1977); and (Leech, 1983). The locutionary act is the actual production of an utterance, the illocutionary act is the intention of the speaker, the action performed by uttering a certain sentence. It is characterized by the illocutionary force, or the intended socially valid verbal action. The same proposition can convey different illocutionary forces and perform different actions in particular contexts, this is because locutionary and illocutionary acts are independent. The perlocutionary act is the actual effect produced by a speech act, like persuading, convincing, scaring, and getting someone to do or to realize something (Licea-Haquet et al., 2019). 


\section{Locutionary Act}

Locutionary act is performing the act of saying something (Leech, 1983). This speech act links the topic with information in expression. The locutionary act is similar to the relationship of principle with predicate or topic with explanation in syntax or subject-predicate and topic-comment (Nababan, 1987) or propositional act (Searle, 1977). The locutionary act of Madurese wedding ceremony in Kalidandan village, Pakuniran, Probolinggo can be seen below. \#Delem pernikahan pastenah benyak cobeen se koduh eyadepin kalaben saber ben jek nuroten nafso, nikah reah tak segempang mabelik tanang. Dalem pernikahan reah mun bedeh selokah tambein lokah jiah, jek sajen palokah sarah\#

'Turning a marriage, there must be many problems that must be dealt patiently and not to indulge in lust because turning marriage is not easy as flip hands. If one gets injury treat it, do not add any more damages'

The data above was spoken by religious authority to inform something that in marriage there must be many problems that must be dealt patiently and not to indulge in lust because turning marriage is not easy as turning hands. If one gets injury treat it, do not add any more damages.

\section{Illocutionary Act}

Illocutionary act is performing an act in saying something (Leech, 1983) or the act of doing something (I. D. P. dan M. R. Wijana, 2011). This illocutionary act is also said to be an expression to state a statement, offer, promise, question, and so on. The illocutionary act of Madurese wedding ceremony in Kalidandan village, Pakuniran, Probolinggo can be seen below. \#Delem pernikahan pastenah benyak cobeen se koduh eyadepin kalaben saber ben jek nuroten nafso, nikah reah tak segempang mabelik tanang. Dalem pernikahan reah mun bedeh selokah tambein lokah jiah, jek sajen palokah sarah\#

'Turning a marriage, there must be many problems that must be dealt patiently and not to indulge in lust because turning marriage is not easy as flip hands. If one gets injury treat it, do not add any more damages' 
Website: http://e-journal.iainsalatiga.ac.id/index.php/jopr/index

The speech above is not only informs something but also to do something. In this case, the speaker tends to order both of them to jointly guard the deficiency of their household, ugliness, and disgrace for other people.

\section{Perlocutionary Act}

Perlocutionary act is performing an act by saying something (Leech, 1983) or the act of affecting someone (I. D. P. dan M. R. Wijana, 2011). This speech act has an influence or perlocutionary force for the hearer. This effect can be intentionally or unintentionally created by the speaker. The data of Madurese wedding ceremony in Kalidandan village, Pakuniran, Probolinggo can be seen below.

\#Delem pernikahan pastenah benyak cobeen se koduh eyadepin kalaben saber ben jek nuroten nafso, nikah reah tak segempang mabelik tanang. Dalem pernikahan reah mun bedeh selokah tambein lokah jiah, jek sajen palokah sarah\#

'Turning a marriage, there must be many problems that must be dealt patiently and not to indulge in lust because turning marriage is not easy as flip hands. If one gets injury treat it, do not add any more damages'

The speech above is not only contains locutionary and illocutionary act but also perlocutionary act which is affects act. It means that this speech expects them to foster their household with responsibility and hopefully they get sakinah, mawadah, warahmah.

\section{Kinds of Speech Act}

The discussion about kinds of speech act is urgently discussed based on modes of the speech act that can be analyzed through utterances. Austin (1962) classified the speech act into five types, namely 1) verdictives: estimating, calculating, and expecting; 2) exercitives: establishing, choosing, ordering, appealing, advising, and warning; 3) commissives: announcing and promising; 4) behabitives: apologizing, congratulating, praising, grieving, condemning, and challenging; 5) expositives: answering, refuting, acknowledging, describing, guessing, and postulating.

Searle (1979) divided the types of speech act into five, namely 1) representative: stating, reporting, showing, and mentioning; 2) directive: ordering, asking, demanding, suggesting, and 
challenging; 3) commissive: promise and swear; 4) expressive: apologize, thank, criticize, and complain; 5) declaration: decide, baptize, canceling, prohibit, permit, and forgive.

Leech (1983) classified the speech act into four types, namely 1) assertive: affirm, allege, assert, forecast, predict, announce, and insist; 2) directive: ask, beg, bid, command, demand, forbid, recommend, and request; 3) commissive: offer, promise, swear, volunteer, and vow; 4) expressive: apologize, commiserate, congratulate, pardon, and thank.

Levinson (1983) classified the speech act into five types, namely 1) representative: state and end; 2) directive: asking and asking questions; 3) commissive: promise, threaten, and offer; 4) expressive: thank, apologize, welcome, and congratulate; 5) declaration: excommunicate, sentence, and baptize.

Yule (1996) also divided the speech act into five types, namely 1) declaration: describe; 2) representative: affirm, conclude, and explain; 3) expressive: hurt, like, dislike, enjoy, and grieve; 4) directive: order, ask for, and suggest; 5) commissive: promise, threaten, and refuse.

Bach (1999) divided the speech act into five types, namely 1) constative: state, accuse, announce, answer, connect, acknowledge, classify, agree, establish, think, deny, refute, dispute, show, debate, introduce, inform, ask, strongly, predict, arrange, report, and determine; 2) directive: giving advice, warning, ask, plead, fire, forgive, prohibit, direct, order, permit, demand, advocate, and appeal; 3) commissive: approve, bet, guarantee, invite, offer, promise, swear, and offering self; 4) acknowledgment: apologize, grieve, congratulate, greeting, thank, accept, and refuse.

I. D. P. Wijana (1996) developed the opinions of Austin (1962), Searle (1977), Leech (1983), Levinson (1983), Yule (1996), and Bach (1999). Wijana divided the speech act in detail into eight types, namely 1) direct speech act;2) indirect speech act; 3) literal speech act; 4) nonliteral speech act; 5) direct literal speech act; 6) indirect literal speech act; 7) direct nonliteral speech act; 8) indirect nonliteral speech act. This study refers to Wijana's concept because it is relevant to be used to analyze the speech modes of Madurese wedding ceremony in Kalidandan village, Pakuniran, Probolinggo. 


\section{Direct Speech Act}

Direct speech act is utterances that have the same meaning with the speech mode, such as interrogative mode to ask question, declarative mode to inform or tell something, and imperative mode to order or command (I. D. P. Wijana, 1996).

\#De'ka tretan Halili gi. Oreng tokar mun bedeh masalah jek nukolan gi! Empean secara adet islam pajet pon tak teppak, secara atoran nagereh empean bedeh hukumah. Manabi abinih oreng binik nyakek'en ka selakek, selakek nyakek'en ka se binik bedeh atornah mangken gi. Jek sampek nukol walaupun bellis ngak napah empean. Laen bik lambek, mun lambek ngucak maceplos sebinik potong sobung napah skaleh. Keng mun semangken, alampet etuntut empean bisah, enggi. Jek sampek engak genikah gi!

Ben se nomer duek, jek pang-gempang ngucak'an pesa gi! Pesa, talak, cerai nikah gi. Walaupun empean delem kabedek'en seneng jek sampe ka ateh.

Ben senomer tellok, bejengah padeh jegeh gi! lima bektonah nika gi! Dedih, mun lima bektonah empean ajegeh, ejegeh bik Allah, enten sementara rejekenah insya Allah tak kerah e paposang. Keng mun tokar, gi pasteh bedeh, keng kor jek jerajein, gi. Jek sampe ujung-ujungnya perceraian, gi. Nik-sekonik pesa, nik-sekonik ngambul, tak lebur te, gi. Napapole empean compok'en semmak nikak, lem malem tokar elang empean tak etemmuh ten. Gi, koduh reng seppo dibik nika pon\#

'To Tn. Halili, if you have problems with your wife, do not be large-handed as like hitting her.

Legally of Islamic customary you will be wrong and also this country has regally rule of law. Now there are rules for husband hurts wife also wife hurts husband. Do not let you hit your wife even you are very angry with her. It is different from the past, beating wife to bruises and fracture it is nothing law. But now, it is just blister, you will be dealing with the law. Do not do it, please!

Number two, do not say divorce easily you are joke. Do not let it be in your heart!

Number three, please keep your prayers together! So, if you keep your five prayer times, you will be guarded by God, God willing he will not complicate your sustenance. There must be quarrels and noise but do not make it as the sustainable problems. Do not let it divorce ending. Do not ever say divorce, please! Bygone is not a good thing. Moreover, your house is near with your wife's house. Do not make bygone as solution. Halili's parent should be as someone who joins controlling your son'

The speech above is direct speech act which conducted by imperative where the speaker gets bridegroom to not be large-handed as like hitting her. Legally of Islamic customary you will be wrong and also this country has regally rule of law. So, the speaker suggests that if there is a problem in their household, better it is solved in a subtle way without any violence. Second, the speaker begs the bridegroom not easily say divorce because it affects ugliness for others 
family. Third, the speaker asks them to keep their prayers and the speaker addresses them, God will keep their sustenance if they keep their prayers.

\section{Indirect Speech Act}

Indirect speech act is utterances that have the different from meaning with the speech mode. For instance, imperative is conducted by interrogative and so on. It means that it is used to be polite (I. D. P. dan M. R. Wijana, 2011).

\#Oreng abinih meloloh tak lebur ben oreng alakeh meloloh yeh tak lebur kiah\# 'Married-divorced is not good things'

The speech above is indirect speech act where it is a declarative mode but this speech means asking. The speaker asks them as they do not easily say divorce. To solve problem is not divorce ending so that the speaker expects them to remind and provide correction each other.

\section{Literal Speech Act}

Literal speech act is utterances that have the same meaning with the spoken mode (I. D. P. dan M. R. Wijana, 2011).

\#Mun lambek pokok'en gun torok ocak, soro alakeh yeh alakeh, soro abinih yeh abinih, tak taoh se etemmuh sapah. Mun steah kan enjek jet lah etemmuh kadek, se toah gik tak taoh se ngudeh lah taoh kadek\#

'Our lives are not the same as life right now. We were told to get married with parents' choice, we obeyed it even though we did not love and know who they were. It is different from teenagers this present. They find their own choices as we just grant it much'

The speech above is literal speech act where it contains statement that teenagers this present is different from at last who obeys on parents' preferences. As the parent, speaker cannot decide their willingness without parents' force. Her children decided their preferences with whom he/she is married. Now speaker just grants what would like they have to.

\section{Non-Literal Speech Act}

Non-literal speech act is utterances that have different meaning or contrary from the spoken (I. D. P. dan M. R. Wijana, 2011).

\#Sala bileh lah. Langsungah akabin beih mareh jek anunah jet lah\# 
Website: http://e-journal.iainsalatiga.ac.id/index.php/jopr/index

'We were wrong at last. It has just been married of right away'

This speech has a contrary meaning with the spoken due. The speaker suggests hearer that she got her children to be married off at the beginning when they got engagement. The illocutionary act of this speech is the speaker felt disappointed and ashamed because her son does not come home from the woman's house. Right now, he has been being as the subject of public discussion. In this case, they do not have consideration of attitude and behavior. They are living together without marriage intercourse.

\section{Direct Literal Speech Act}

Direct literal speech act is a combination speech between direct speech act and literal speech act. Literal speech act is utterance that literally expressed with the same mode and meaning (I. D. P. dan M. R. Wijana, 2011)

\#Mun bedeh konlelakon edinnak, poko'lah jek gukseguk dekyeh senyuroah\# 'If there are some activities to work, do not hesitate to ask him back up you'

This speech has the same mode and meaning with what speak for. It means that the speaker instructs the hearer to not hesitate to ask her son helping some activities related to working in family.

\section{Indirect Literal Speech Act}

Indirect literal speech act is utterance expressed with unusual sentences mode of the speaker intention but it has literally meaning with what speaker utterances for such as imperative is expressed by asking and so on (I. D. P. dan M. R. Wijana, 2011).

\#Setoah padeh setuah yeh dekyeh, padeh jek dematdeih mun reng ngudeh yeh jet lah laen bik se toah, se toah reh jet lah mareh ngudeh, yeh lah neng-neng dekyeh\#

'We are as parents should not listen what people say about our children. Our life is different from now and we had ever experienced it'

This speech is constructed by an imperative sentence. The illocutionary act of this sentence is the speaker gets hearer to be patient dealing with the bad news toward their children. The speaker expect hearer to be patient hearing bad news about them who judged as no morals, attitude, and behavior because they often stayed out before getting married. 


\section{Direct Non-literal Speech Act}

Direct non-literal speech act is utterance expressed by a sentence with a purpose of accordance speech but it does not have the same meaning as the words is conducted by speaker (I. D. P. dan M. R. Wijana, 2011).

\#Benni dekremmah, mun steah kan tana celleng, jek apola\#

'Realize please that the ground is still black right now'

This speech showed that the speaker expresses a declarative sentence to inform something, namely the ground is still black right now. On the other hand, this sentence means request. It means that the speaker beg hearer to postpone wedding party because she does not have money. The speaker expects hearer to understand her situations and conditions.

\section{Indirect Non-literal Speech Act}

Indirect non-literal speech act is utterance expressed by different mode and different meaning from the sentence spoken (I. D. P. dan M. R. Wijana, 2011).

\#Abekalnah gik ngangguyeh taonan. Dinah rah mun gun anak'en lah tak mole jek rukeburuh, sanmisan nyareh tadinan senyaman. Can oreng nyareagin anak'en ben kedik bedeh budinah! Ngucak kok, apanah senyareaginah anak neng bik bekalah roah\#

'Engagement needs years times. Understand please if recently our children have not gone home. Let me find a nice day and date of their wedding later. People said to me that they got me to find someone's opinion. "It is afraid of having bad ending". I told them that no need to find other' opinion because my son lived with his girl'.

This speech showed that the speaker expressed a sentence with different mode and different meaning from speaker's goal. The speaker declared something to hearer that people reported their children's relationship. People considered that their children's relationship were outside of behavior and religious law because their children were often living and staying together. However, the illocutionary act of this speech is asking hearer to marriage them immediately because it is feared that she gets pregnant under married. The expected action of this speech is his children can be married immediately so that they do not abusive and embarrassing. 
Website: http://e-journal.iainsalatiga.ac.id/index.php/jopr/index

\section{REFERENCES}

Austin, J. L. (1962). How to Do Things with Words. Oxford University Press.

Bach, K. (1999). The Semantics-Pragmatics Interface from Different Points of View. Elsevier, 65--84.

Bawa, I. W. (2004). Wibawa Bahasa. Program Pascasarjana (S2-S3) Linguistik Universitas Udayana.

Fetrina Rahma Dewi. (2010). Geografi Dialek Bahasa Madura Di Daerah Pesisir Probolinggo. Artikulasi, 9(1), 609-622.

Foley, W. . (1977). Anthropological Linguistics. Blackwell Publisher Inc.

Hodge, R. and G. K. (1988). Social Semiotics. Polity Press.

Jendra, I. W. (2009). Intisari Sejarah Linguistik. Paramita.

Leech, G. (1983). The Principles of Pragmatics. Longman.

Levinson, C. S. (1983). Pragmatics. Cambridge University Press.

Licea-Haquet, G. L., Velásquez-Upegui, E. P., Holtgraves, T., \& Giordano, M. (2019). Speech act recognition in Spanish speakers. Journal of Pragmatics, 141, 44-56. https://doi.org/10.1016/j.pragma.2018.12.013

Moleong, L. J. (2004). Metodologi Penelitian Kualitatif. PT Remaja Rosdakarya.

Nababan, P. W. . (1987). Ilmu Pragmatik (Teori dan Penerapannya). Departemen Pendidikan dan Kebudayaan Direktorat Jenderal Pendidikan Tinggi, Proyek Pengembangan Lembaga Pendidikan Tenaga Kependidikan.

Searle, John, 1969. Speech Acts: An Essay in the Philosophy of Language. Cambridge University Press, Cambridge.

Searle, John, 1975. A taxonomy of illocutionary acts. In: Günderson, K. (Ed.), Language, Mind and Knowledge, vol. 7. University of Minnesota Press, Minneapolis, pp. 344e369.

Searle, R. J. (1977). Speech Act. Cambridge University Press.

Searle, R. J. (1979). Expression and Meaning. Cambridge University Press.

Sudaryanto. (1993). Metode dan Aneka Teknik Aanalisis Bahasa: Pengantar Penelitian Wahana Kebudayaan secara Linguistik. Duta Wacana University Press.

Tarigan, H. G. (1983). Menyimak sebagai Suatu Keterampilan Berbahasa. Angkasa.

Tsoumou, J. M. (2020). Analysing speech acts in politically related Facebook communication. Journal of Pragmatics, 167, 80-97. https://doi.org/10.1016/j.pragma.2020.06.004 
Weigand, Edda, 2010. Dialogue: The Mixed Game. John Benjamins Publishing Company, Amsterdam/Philadelphia.

Wijana, I. D. P. (1996). Dasar-Dasar Pragmatik. Andi.

Wijana, I. D. P. dan M. R. (2011). Analisis Wacana Pragmatik, Kajian Teori dan Analisis. Yuma Pustaka.

Yoschitake, Masaki, 2004. Critique of J. L. Austin's speech act theory: Decentralization of the speaker-Centered meaning in communication. Kyushu Communication Studies 2, 27e43 (Communication Association of Japan Kyushu Chapter).

Yule, G. (1996). Pragmatics. Oxford University Press. 